\title{
Corynebacterium confusum sp. nov., isolated from human clinical specimens
}

\author{
Guido Funke, ${ }^{1}$ Carlos R. Osorio, ${ }^{2}$ Reno Frei, ${ }^{3}$ Philippe Riegel ${ }^{4}$ \\ and Matthew D. Collins ${ }^{2}$
}

\author{
Author for correspondence: Guido Funke. Tel: +411634 2701. Fax: +4116344906 \\ e-mail : funke@immv.unizh.ch
}

\footnotetext{
1 Department of Medical Microbiology, University of Zurich, 8028 Zurich, Switzerland

2 Department of Microbiology, BBSRC Institute of Food Research, Reading RG6 6BZ, UK

3 Department of Laboratory Medicine, Microbiology Laboratory, Kantonsspital Basle, 4031 Basle, Switzerland

4 Institut de Bactériologie, Faculté de Médecine, Université Louis Pasteur Hopitaux Universitaires, 67000 Strasbourg, France
}

\begin{abstract}
Three strains of a previously unknown coryneform bacterium were isolated from two patients with foot infections and from a blood culture of a third patient. The three non-lipophilic strains exhibited very slow fermentative acid production from glucose but not from maltose or sucrose, nitrate reductase activity, no tyrosinase activity and the presence of small amounts of tuberculostearic acid as the most significant phenotypic features. Differentiation of these strains from all other presently defined coryneform bacteria was readily achieved. Chemotaxonomic investigations revealed that the three strains unambiguously belonged to the genus Corynebacterium. Comparative 165 rRNA gene sequence analysis demonstrated that the isolates were almost identical and represented a new subline within the genus Corynebacterium, for which the designation Corynebacterium confusum sp. nov. is proposed. The type strain of Corynebacterium confusum is CCUG $38267^{\top}$.
\end{abstract}

Keywords: Corynebacterium, Corynebacterium confusum sp. nov., phenotypical delineation, $16 \mathrm{~S}$ rRNA gene, phylogeny

\section{INTRODUCTION}

Clinical microbiologists have only in recent years started to realize the enormous diversity of coryneform bacteria encountered in human clinical specimens. Within the group of coryneform bacteria (i.e. aerobically growing, irregular, asporogenous, Gram-positive rods) the genus Corynebacterium is the one comprising the largest number of validated species (more than 40 as of January 1998) (Collins \& Cummins, 1986; Fernandez-Garayzabal et al., 1997; Funke et al., 1997a-e; Riegel et al., 1997a, b; Sjödén et al., 1998; Zimmermann et al., 1998). It is important to note that 16 of these species had been defined within the past 5 years and that all of them, with the exception of Corvnebacterium mastitidis, were recovered from human clinical materials. This was mainly because of the development of more sophisticated phenotypical identification systems, the more consistent application of chemotaxonomic methods, as well as the extensive use of molecular genetic methods such as $16 \mathrm{~S}$ rRNA

The EMBL accession number for the $16 \mathrm{~S}$ rRNA of strain DMMZ $2439^{\top}$ (CCUG $38267^{\top}$ ) is $Y 15886$. gene analysis. This report is on yet another novel Corynebacterium isolated from humans. Using a polyphasic approach to taxonomy, we describe three strains of a previously unknown member of the genus Corynebacterium. Based on the results of this study a new species, Corynebacterium confusum, is proposed.

\section{METHODS}

Strains used and culture conditions. The three strains studied were DMMZ (Department of Medical Microbiology, University of Zurich, Switzerland) $2439^{\mathrm{T}}$, DMMZ 3259 and IBS (Institut de Bactériologie, Strasbourg, France) T88848. The first two strains had primarily been isolated from Columbia agar plates (Difco) supplemented with $5 \%$ sheep blood agar (SBA) and incubated for $24 \mathrm{~h}$ at $37{ }^{\circ} \mathrm{C}$ in a $5 \% \mathrm{CO}_{2}$-enriched atmosphere. The same conditions were used for subculturing of all three strains. Strain IBS T88848 was initially grown from a Bactec aerobic NR6A blood culture system (Becton Dickinson).

Biochemical profiles. The methods used for determination of the biochemical profiles have been described previously (Funke et al., 1993). The API CORYNE strips (bioMérieux) were read after $24 \mathrm{~h}$ incubation, except for acid production from carbohydrates, in which case they were read after $72 \mathrm{~h}$. For the API 50CH system applying the $50 \mathrm{CHE}$ medium 
(both from bioMérieux), the end reading was performed after $240 \mathrm{~h}$ incubation at $37^{\circ} \mathrm{C}$ in ambient air. Hydrolysis of tyrosine was observed on a medium described previously (Nash \& Krenz, 1991); a positive reaction was defined as clearing of the medium after $240 \mathrm{~h}$ incubation at $37^{\circ} \mathrm{C}$ in ambient air.

Antimicrobial susceptibility patterns. The minimal inhibitory concentrations (MICs) of 19 agents were determined with the Merlin Micronaut system (Merlin Diagnostics, Bornheim-Hersel, Germany) and interpreted according to breakpoints established by the National Committee for Clinical Laboratory Standards as described previously (Funke et al., 1997f).

Chemotaxonomic investigations. Cellular fatty acid patterns were determined with the Sherlock system (Microbial ID) as outlined previously (von Graevenitz et al., 1991). Techniques used for analyses of whole-cell hydrolysates for the presence of meso-diaminopimelic acid and of mycolic acids were also as described previously (Funke et al., 1993).

Molecular genetic investigations. A large fragment (around 1500 bases) of the $16 \mathrm{~S}$ rRNA gene of strains DMMZ $2439^{\mathrm{T}}$ and 3259 was amplified by PCR by using universal primers $\mathrm{pA}$ and $\mathrm{pH}^{*}$ as described previously by Hutson et al. (1993). The PCR products were purified by using a Prep-A-Gene kit (Bio-Rad) and were sequenced by using a Taq DyeDeoxy Terminator Cycle Sequencing kit (Applied Biosystems) and a model 373A automatic sequencer (Applied Biosystems). The sequences determined were aligned with those of phylogenetically close reference species (i.e. other high$\mathrm{G}+\mathrm{C}$-content actinomycetes) obtained from the EMBL database by using the program PILEup (Devereux et al., 1984), and the alignment was corrected manually. An unrooted phylogenetic tree was constructed by using the neighbour-joining method (Saitou \& Nei, 1987). Stability of relationships was assessed using the programs SEQBOOT, DNADIST, NEIGHBOR and CONSENSE of the PHYLIP package (Felsenstein, 1989).

\section{RESULTS AND DISCUSSION}

Strain DMMZ $2439^{\mathrm{T}}$ was isolated from a 36 -year-old man with a plantar abscess and strain DMMZ 3259 grew from bone material of a 40-year-old man with osteomyelitis of the calcaneus. Neither of the patients had diabetes. Strain IBS T88848 was isolated only once: from the blood of a 20 -year-old, non-immunocompromised man with transient fever after thoracic surgery. When cultured on aerobic SBA plates, the three strains grew as whitish, glistening, convex, creamy colonies of up to $1.5 \mathrm{~mm}$ in diameter after $48 \mathrm{~h}$ incubation. The strains were non-lipophilic and grew only weakly in a strict anaerobic atmosphere to colonies of $0.5 \mathrm{~mm}$ diameter after $48 \mathrm{~h}$ incubation. Gram stains showed often relatively short but typically club-shaped coryneform bacteria (seen in genuine Corynebacterium species only: Collins \& Cummins, 1986; Funke et al., 1997e) of 1-3 $\mu \mathrm{m}$ in length which were arranged as single cells, in pairs or in small clusters. The three strains were not partially acid-fast.

When initially applying the phenotypic identification system for coryneform bacteria outlined recently (von Graevenitz \& Funke, 1996), we observed the following reactions: catalase-positive; non-motile rods; nitrate reduction-positive; no hydrolysis of urea or aesculin; no acid production from glucose, maltose, sucrose, mannitol or xylose in cystine-trypticase agar (CTA) medium after $10 \mathrm{~d}$ incubation, although the alkalinization reaction of glucose was judged as weaker than for the other four carbohydrates. However, when acidification of glucose was determined in the independent API CORYNE and API 50CH systems, acid formation from glucose was positive although delayed, i.e. the reaction became positive after $48-72 \mathrm{~h}$ only. Obviously, the stronger buffering capacity of the CTA medium prevented the indication of an acid production from glucose. For all three strains, we observed the numerical code 3100304 (after $72 \mathrm{~h}$ ) when applying the API CORYNE system. This corresponded to a very good identification of the strains on the genus level as Corynebacterium and on the species level as either Corynebacterium striatum/Corynebacterium amycolatum or Corynebacterium jeikeium according to the system's database (API CORYNE Analytical Profile Index $2.0 ; 1997)$. If the strains had been incubated for only $24 \mathrm{~h}$, as recommended by the manufacturer, a numerical code of 3100004 would have been generated, which corresponds to an identification of the isolates as Corynebacterium propinquum. The same result was obtained when using the identification scheme of von Graevenitz \& Funke (1996). However, as mentioned above, the three unknown coryneform bacteria produced acid from glucose in the above API systems, which is not observed in C. propinquum isolates (Riegel et al., 1993). In addition, unlike C. propinquum (Riegel et al., 1993), all three strains did not hydrolyse tyrosine. The same test served to distinguish the isolates from $C$. striatum strains, which also invariably hydrolyse tyrosine (Table 1). The three strains were initially also considered to represent Corynebacterium coyleae strains, but the latter species does not reduce nitrate and exhibits a strong CAMP reaction (Table 1). Strains DMMZ 2439' ${ }^{\prime}$, DMMZ 3259 and IBS T88848 phenotypically also resemble Corynebacterium argentoratense (Table 1), but strains belonging to this taxon are always nitrate reductase-negative and exhibit chymotrypsin activity, so that an assignment of the three unknown strains to this taxon could also be ruled out. Finally, Corynebacterium amycolatum strains may have a biochemical profile identical to the one of the three unknown coryneform bacteria DMMZ $2439^{\mathrm{T}}$, DMMZ 3259 and IBS T88848, but C. amycolatum exhibits dry and rough colonies, which is incompatible with the morphology of the unknown coryneforms described in this report (see above).

Further evidence for the distinctiveness of the three clinical isolates came from the chromatographic analysis of mycolic acids. All three strains were found to contain short-chain mycolic acids, whereas $C$. amycolatum strains always lack these lipids. Meso-diaminopimelic acid was found to be the diamino acid of the peptidoglycan. The major cellular fatty acids were 
Table 1. Characteristics that differentiate Corynebacterium confusum from other fermenting, non-lipophilic Corynebacterium spp. encountered in human clinical specimens

Data according to Collins \& Cummins (1986), Funke et al. (1997a, c-e), Riegel et al. (1997a, b), Sjödén et al. (1998), Zimmermann et al. (1998). (), Delayed reaction; v, variable reaction; w, weak reaction; REV, reverse CAMP reaction.

\begin{tabular}{|c|c|c|c|c|c|c|c|c|c|c|}
\hline \multirow[t]{2}{*}{ Species } & \multirow{2}{*}{$\begin{array}{l}\text { Nitrate } \\
\text { reduction }\end{array}$} & \multirow{2}{*}{$\begin{array}{c}\text { Urea } \\
\text { hydrolysis }\end{array}$} & \multirow{2}{*}{$\begin{array}{l}\text { Aesculin } \\
\text { hydrolysis }\end{array}$} & \multirow{2}{*}{$\begin{array}{l}\text { Pyrazin- } \\
\text { amidase }\end{array}$} & \multirow{2}{*}{$\begin{array}{c}\text { Alkaline } \\
\text { phosphatase }\end{array}$} & \multicolumn{3}{|c|}{ Acid produced from: } & \multirow{2}{*}{$\begin{array}{l}\text { CAMP } \\
\text { reaction }\end{array}$} & \multirow[t]{2}{*}{ Other traits } \\
\hline & & & & & & Glucose & Maltose & Sucrose & & \\
\hline C. confusum & + & - & - & + & + & $(+)$ & - & - & - & Tyrosine hydrolysis- \\
\hline C. amycolantum & v & $\mathrm{v}$ & & + & + & + & $\mathrm{v}$ & $\mathrm{v}$ & - & Mycolic acids - \\
\hline C. argentoratersese & - & & & + & $v$ & + & - & - & & Chymotrypsin + \\
\hline C. coyleae & - & - & - & + & + & $(+)$ & - & - & + & \\
\hline C. diphtheriat & $\mathrm{v}$ & - & - & & - & + & + & - & - & Cystinase + \\
\hline C. durum & + & (v) & (v) & + & - & + & + & + & - & Adherence to agar \\
\hline C. falsenii & - & $(+)$ & - & w & + & $(+)$ & $\mathrm{v}$ & - & - & Yellowish \\
\hline C. glucuronolyicum & $\mathrm{v}$ & $\mathrm{v}$ & $\mathrm{v}$ & + & $\mathrm{v}$ & + & $\mathrm{v}$ & + & + & $\beta$-Glucuronidase + \\
\hline C. imitans & - & - & - & $w$ & + & + & + & w & + & Tyrosine hydrolysis- \\
\hline C. minutisimum & - & - & - & + & + & + & + & $\mathrm{v}$ & - & Tyrosine hydrolysis + \\
\hline C. pseudotuheriulesis & & + & - & - & v & + & + & $\mathrm{v}$ & REV & Glycogen -- \\
\hline C. riegelii & - & + & - & $\mathrm{v}$ & $v$ & - & $(+)$ & - & - & \\
\hline C. singular & - & + & - & + & + & + & + & + & - & Tyrosine hydrolysis+ \\
\hline C. striatum & + & - & - & + & + & + & - & v & $v$ & Tyrosine hydrolysis + \\
\hline C. thomssemii & - & + & - & + & + & + & + & + & & $N$-Acetylglucosaminidase + \\
\hline C. utcerans & - & + & & - & + & + & + & - & REV & Glycogen + \\
\hline C. terosis & $\mathrm{v}$ & & - & + & + & + & + & + & -. & Yellowish \\
\hline
\end{tabular}

$\mathrm{C}_{16: 0}\left(27-29 \%\right.$ of all cellular fatty acids), $\mathrm{C}_{18: \omega 9 \mathrm{c}}$ $(34-35 \%)$ and $\mathrm{C}_{18: 0}(7-9 \%)$. Significant amounts of tuberculostearic acid $(2-3 \%)$ were also detected. As a result of the chemotaxonomic investigations, the three unknown coryneform bacteria could be unambiguously identified as Corynebacterium species (Collins \& Cummins, 1986). Tuberculostearic acid is relatively rarely detected in non-lipophilic fermentative corynebacteria. In fact, Corynebacterium minutissimum and Corynebacterium xerosis are the only two non-lipophilic, fermentative corynebacteria in which tuberculostearic acid is detected (Bernard et al., 1991; von Graevenitz et al., 1991).

Determination of MICs (in $\mu \mathrm{g} \mathrm{ml}^{-1}$ ) revealed that the strains were susceptible to penicillins (e.g. penicillin $\mathrm{G}$ $0.0625-0.25$, ticarcillin $0.5-2$ ), most cephalosporins (e.g. cephalothin $\leqslant 0 \cdot 125-0.25$, ceftriaxone $0.5-1$ ), aminoglycosides (e.g. amikacin $0 \cdot 25-1$, tobramycin $0.125-0.25$ ), tetracyclines (e.g. doxycycline 0.25-1, minocycline $0 \cdot 25-1$ ), quinolones (e.g. ciprofloxacin $0.0625-0.25$, ofloxacin $0 \cdot 5-1$ ), chloramphenicol (2-4), fusidic acid $(0.0625-0.5)$ and glycopeptides (e.g. teicoplanin $0 \cdot 5$, vancomycin 1). Strain DMMZ 3259 was resistant to rifampicin (MIC >32) whereas strains DMMZ $2439^{\mathrm{T}}$ and IBS T 88848 were susceptible (MIC $\leqslant 0 \cdot 02$ ). Strain IBS T88848 was resistant to macrolides (e.g. erythromycin and clarithromycin), whereas the other two strains were susceptible. All strains were resistant to aztreonam $(>64)$ and fosfomycin $(>256)$. Overall, the antimicrobial susceptibility pattern of the three unknown coryneform bacteria corresponded to that of many other non-lipophilic corynebacteria (Funke et al., 1997f).

To determine the phylogenetic relatedness of strains DMMZ 2439 ${ }^{\mathrm{T}}$ and DMMZ 3259, their 16S rRNA genes were amplified by PCR and subjected to sequence analysis. The almost complete $16 \mathrm{~S}$ rRNA gene sequences ( $>1400$ nucleotides) of both strains were determined and comparative sequence analysis revealed only four nucleotide differences between the isolates (approx. 99.7\% sequence similarity), thereby demonstrating their genealogical homogeneity. Sequence searches of EMBL/GenBank databases using the FASTA program revealed that the newly determined sequences were most closely related to species of the genus Corynebacterium (16S rRNA sequence similarities $>92 \%$ ). Significantly lower levels of relatedness were shown with other actinomycete taxa (data not shown). A tree depicting the phylogenetic relationships of the unidentified bacterium within the genus Corynebacterium is shown in Fig. 1. C. propinquum and Corynebacterium pseudodiphtheriticum were found to be the closest phylogenetic relatives of the new bacterium. However, a sequence divergence value of $>4 \%$ unambiguously demonstrates that the unknown Corynebacterium represents a new species (Stackebrandt \& Goebel, 1994). Riegel et al. (1993) had already demonstrated that strain IBS T88848 exhibits only a $5-10 \%$ DNA-DNA homology with the type strain of Corynebacterium propinquum and only 1-2\% DNA-DNA homology with $C$. pseudodiphtheriticum. In addition, strain IBS T88848 did not show high DNA-DNA relatedness with a variety of other Corynebacterium species examined (Riegel et al., 1993). These data are consistent with the findings of the comparative 16S rRNA gene sequence analysis and confirm that the three unknown strains represent a new species.

It is apparent that the new Corynebacterium species is only rarely encountered in the clinical environment, but it seems most likely that other clinical micro- 


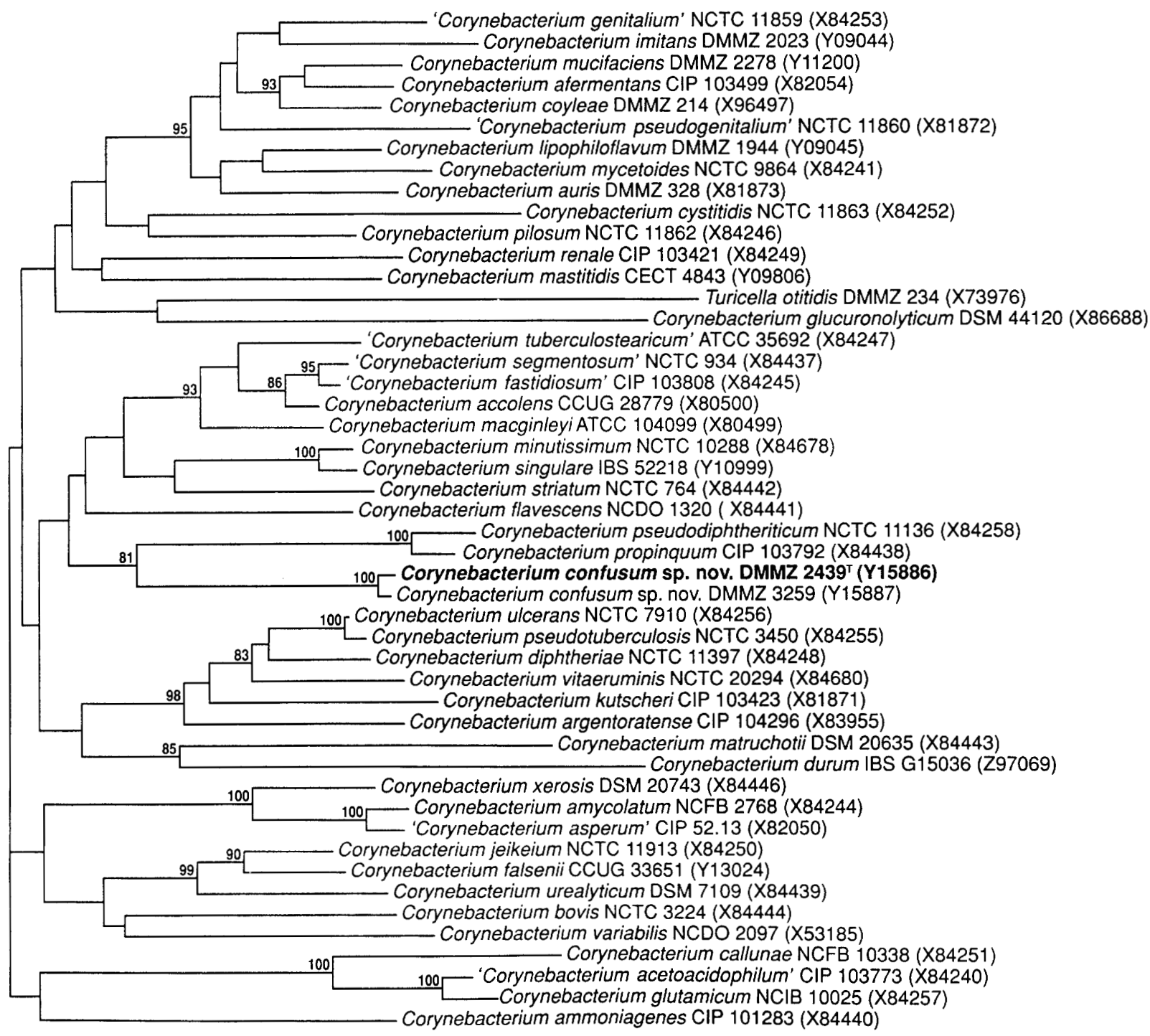

Fig. 1. Unrooted tree showing the phylogenetic position of Corynebacterium confusum within the genus Corynebacterium. The tree, constructed using the neighbour-joining method, was based on a comparison of approximately 1330 nucleotides. Bootstrap values, expressed as a percentage of 200 replications, are given at the branching points. Strains used are given and their corresponding 16S rRNA sequence accession numbers are given in parentheses.

biologists will also recognize it once it has been described in the literature. As many clinical laboratories use the API CORYNE strip for identification of coryneform bacteria, the weak acid formation from glucose exhibited by the new Corynebacterium may be recognized more easily, leading to the correct identification and avoiding the false-negative result observed in CTA media. Weak acidification of CTA media is also observed in the recently described $C$. coyleae (Funke et al., 1997d), Corynebacterium mucifaciens (Funke et al., 1997c) and Corynebacterium riegelii (Funke et al., 1998), all of which might be misidentified if acidification reactions are not read after an extended time period, i.e. 48 or $72 \mathrm{~h}$ instead of $24 \mathrm{~h}$.
This report once more demonstrates the importance of identifying coryneform bacteria from clinical specimens to the species level, as in this way new bacterial species might be discovered. Based on the results of the phenotypic and molecular genetic findings, we therefore propose that the above-described coryneform bacterium should be classified as a new species of the genus Corynebacterium, for which the name Corynebacterium confusum sp. nov. is proposed.

\section{Description of Corynebacterium confusum sp. nov.}

Corynebacterium confusum (con.fu'sum. L. past part. confusum confusing, to indicate that this bacterium 
might be phenotypically confused with many other Corynebacterium species).

The description given below is based on the results of the studies of three strains. Cells are Gram-positive, non-spore-forming and non-motile. They are typically club-shaped rods that occur as single cells, in pairs or in small clusters. Colonies are whitish, glistening, convex, creamy and up to $1.5 \mathrm{~mm}$ in diameter after $48 \mathrm{~h}$ incubation. Weak anaerobic growth. Catalasepositive. Acid is produced from D-glucose, ribose, Dfructose, tagatose and 5-ketogluconate, but acid is not produced from maltose, sucrose, mannitol, D-xylose, glycerol, erythritol, arabinose, adonitol, $\beta$-methylxyloside, galactose, L-sorbose, rhamnose, dulcitol, inositol. sorbitol, methyl $\alpha$-D-mannoside, methyl $\alpha$-Dglucoside, $N$-acetylglucosamine, amygdalin, arbutin, salicin, cellobiose, lactose, melibiose, trehalose, inulin, melezitose, D-raffinose, glycogen, xylitol, D-turanose, D-lyxose, fucose, arabitol, gluconate or 2-ketogluconate. Acid production from $\beta$-gentiobiose is variable. Nitrate is reduced. Urea, aesculin and tyrosine are not hydrolysed. The CAMP reaction is negative. Activities of pyrazinamidase, alkaline phosphatase, esterase $\left(\mathrm{C}_{4}\right)$ and esterase lipase $\left(\mathrm{C}_{8}\right)$ are detected, whereas pyrrolidonyl arylamidase, valine arylamidase, trypsin, chymotrypsin, $\alpha$-galactosidase, $\beta$-galactosidase, $\beta$-glucuronidase, $\alpha$-glucosidase, $\beta$-glucosidase, $N$ acetyl- $\beta$-glucosaminidase, $\alpha$-mannosidase and $\alpha$ fucosidase are not detected. Activities of leucine arylamidase and phosphoamidase are variable. The cell wall contains meso-diaminopimelic acid. Mycolic acids are present. The main straight-chain saturated fatty acids are palmitic and stearic acids; oleic acid is the predominant unsaturated fatty acid. Minor amounts of tuberculostearic acid are present. Isolated from human clinical specimens. The type strain DMMZ $2439^{\mathrm{T}}$ has been deposited in the Culture Collection of the University of Gothenburg, Sweden, as strain CCUC $38267^{\mathrm{T}}$. It has the features described above except that acid production from $\beta$-gentiobiose is positive and activities of leucine arylamidase and phosphoamidase are detected.

\section{ACKNOWLEDGEMENTS}

We thank A. von Graevenitz for a careful review of the manuscript. This study was funded in part by the European Union (BIO2-CT94-3098) and the Swiss National Science Foundation (contract 3100-050648 97/1). G.F. is a recipient of an ESC MID research fellowship.

\section{REFERENCES}

Bernard, K. A., Bellefeuille, M. \& Ewan, E. P. (1991). Cellular fatty acid composition as an adjunct to the identification of asporogenous. aerobic gram-positive rods. J Clin Microbiol 29 , 83-89.

Collins, M. D. \& Cummins, C. S. (1986). Genus Corynebacterium. In Berge'y' Manual of Systematic Bacteriology, vol. 2, pp. 1266-1276. Edited by P. H. A. Sneath, N. S. Mair, M. E. Sharpe \& J. G. Holt. Baltimore: Williams \& Wilkins.

Devereux, J., Haeberli, P. \& Smithies, D. (1984). A comprehensive set of sequence analysis programmes for the VAX. Nucleic Acids Res 12, 387-395.

Felsenstein, J. (1989). PHYLIP - phylogeny inference package (version 3.2). Cladistics 5, 164-166.

Fernandez-Garayzabal, J. F., Collins, M. D., Hutson, R. A., Fernandez, E., Monasterio, R., Marco, J. \& Dominguez, L. (1997). Corynebacterium mastitidis sp. nov., isolated from milk of sheep with subclinical mastitis. Int J Syst Bacteriol 47, 1082-1085.

Funke, G., Martinetti Lucchini, G., Pfyffer, G. E., Marchiani, M. \& von Graevenitz, A. (1993). Characteristics of CDC group 1 and group 1-like coryneform bacteria isolated from clinical specimens. J Clin Microbiol 31, 2907-2912.

Funke, G., Efstratiou, A., Kuklinska, D., Hutson, R. A., De Zoysa, A., Engler, K. H. \& Collins, M. D. (1997a). Corynebacterium imitans sp. nov. isolated from patients with suspected diphtheria. J Clin Microbiol 35, 1978-1983.

Funke, G., Hutson, R. A., Hilleringmann, M., Heizmann, W. R. \& Collins, M. D. (1997b). Corynebacterium lipophiloflavum sp. nov. isolated from a patient with bacterial vaginosis. FEMS Microbiol Lett 150, 219-224.

Funke, G., Lawson, P. A. \& Collins, M. D. (1997c). Corynebacterium mucifaciens sp. nov., an unusual species from human clinical material. Int $J$ Syst Bacteriol 47, 952-957.

Funke, G., Pascual Ramos, C. \& Collins, M. D. (1997d). Corynebacterium coyleae $\mathrm{sp}$. nov., isolated from human clinical specimens. Int J Syst Bacteriol 47, 92-96.

Funke, G., von Graevenitz, A., Clarridge, J. E., III \& Bernard, K. A. (1997e). Clinical microbiology of coryneform bacteria. Clin Microbiol Rev 10, 125-159.

Funke, G., Alvarez, N., Pascual, C., Falsen, E., Akervall, E., Sabbe, L., Schouls, L., Weiss, N. \& Collins, M. D. (1997f). Actinomyces europaeus sp. nov., isolated from human clinical specimens. Int $J$ Syst Bacteriol 47, 687-692.

Funke, G., Lawson, P. A. \& Collins, M. D. (1998). Corynebacterium riegelii sp. nov., an unusual species isolated from female patients with urinary tract infections. J Clin Microbiol 36, 624-627.

von Graevenitz, A. \& Funke, G. (1996). An identification scheme for rapidly and aerobically growing gram-positive rods. Zentbl Bakteriol 284, 246-254.

von Graevenitz, A., Osterhaut, G. \& Dick, J. (1991). Grouping of some clinically relevant gram-positive rods by automated fatty acid analysis. APMIS 99, 147-154.

Hutson, R. A., Thompson, D. E. \& Collins, M. D. (1993). Genetic interrelationships of saccharolytic Clostridium botulinum types $\mathrm{B}, \mathrm{E}$, and $\mathrm{F}$ and related clostridia as revealed by small-subunit rRNA gene sequences. FEMS Microbiol Lett 108, 103-110.

Nash, P. \& Krenz, M. M. (1991). Culture media. In Manual of Clinical Microbiology, 5th edn, pp. 1226-1288. Edited by A. Balows, W. J. Hausler, Jr, K. L. Herrmann \& H. D. Shadomy. Washington, DC: American Society for Microbiology.

Riegel, P., de Briel, D., Prévost, G., Jehl, F. \& Monteil, H. (1993). Proposal of Corynebacterium propinquum sp. nov. for Corynebacterium group ANF-3 strains. FEMS Microbiol Lett 113, 229-234.

Riegel, P., Heller, R., Prévost, G., Jehl, F. \& Monteil, H. (1997a). Corynebacterium durum sp. nov., from human clinical specimens. Int J Syst Bacteriol 47, 1107-1111.

Riegel, P., Ruimy, R., Renaud, F. N. R., Freney, J., Prévost, G., Jehl, F., Christen, R. \& Monteil, H. (1997b). Corynebacterium singulare sp. nov., a new species for urease-positive strains related to Corynebacterium minutissimum. Int $J$ Syst Bacteriol 47, $1092-1096$. 
G. Funke and others

Saitou, N. \& Nei, M. (1987). The neighbor-joining method: a new method for reconstructing phylogenetic trees. Mol Biol Evol 4 , $406-425$.

Sjöden, B., Funke, G., Izquierdo, A., Akervall, E. \& Collins, M. D. (1998). Description of some coryneform bacteria isolated from human clinical specimens as Corynebacterium falsenii sp. nov. Int $J$ Syst Bacteriol 48, 69-74.

Stackebrandt, E. \& Goebel, B. M. (1994). Taxonomic note: a place for DNA-DNA reassocciation and 16S rRNA sequence analysis in the present species definition in bacteriology. Int $J$ Syst Bacteriol 44, 846-849.

Zimmermann, O., Spröer, C., Kroppenstedt, R. M., Fuchs, E., Köchel, H. G. \& Funke, G. (1998). Corynebacterium thomssenii sp. nov., a Corynebacterium with $N$-acetyl- $\beta$-glucosaminidase activity from human clinical specimens. Int $J$ Syst Bacteriol 48 $489-494$. 